\title{
PERBANDINGAN MODEL PEMBELAJARAN KOOPERATIF TIPE JIGSAW DAN TIPE TWO STAY TWO STRAY TERHADAP HASIL BELAJAR SISWA PADA MATERI ELASTISITAS
}

\author{
Miftahul Anwar ${ }^{1}$, Hadma Yuliani ${ }^{2}$, Sri Fatmawati $^{3}$ \\ 1,2,3 Prodi Pendidikan Fisika IAIN Palangka Raya, Indonesia \\ Email :anwarmiftahul83@gmail.com
}

Info Artikel

Diterima:

30 Juli 2018

Disetujui:

05 November 2019

Dipublikasikan:

15 Desember 2018

Alamat Korespondensi:

anwarmiftahul83@gmail.com

\begin{abstract}
Abstrak:
Penelitian ini bertujuan untuk mengetahui (1) terdapat tidaknya peningkatan yang signifikan hasil belajar siswa menggunakan model kooperatif tipe jigsaw dan tipe two stay two stray, (2) terdapat tidaknya perbedaan yang signifikan hasil belajar siswa menggunakan model kooperatif tipe jigsaw dan tipe two stay two stray, (3) aktivitas guru dan siswa yang menggunakan model kooperatif tipe jigsaw dan tipe two stay two stray. Penelitian ini menggunakan pendekatan kuantitatif dengan jenis penelitian deskripitif dan komparatif. Desain penelitian menggunakan the static group pretest-posttest design dengan pengambilan sampel menggunakan teknik judgment sampling, sampel yang dipilih yaitu kelas XI-IA 5 dan XI-IA 6. Penelitian ini dilaksanakan di MAN Kota Palangka Raya pada bulan September sampai dengan Oktober 2017.Instrumen yang digunakan adalah hasil belajar kognitif, lembar pengamatan hasil belajar afektif dan psikomotorik, aktivitas guru dan siswa.Hasil penelitian diperoleh: (1) terdapat peningkatan yang signifikan hasil belajar siswa dengan model kooperatif tipe jigsaw dan tipe two stay two stray, (2) tidak terdapat perbedaan yang signifikan hasil belajar siswa yang diajar dengan model kooperatif tipe jigsaw dan tipe two stay two stray, (3) aktivitas guru menggunakan model kooperatif tipe jigsaw nilai rata-rata 82,89 dengan kategori baik dan model kooperatif tipe two stay two stray nilai rata-rata 84,20 dengan kategori baik, aktivitas siswa menggunakan model kooperatif tipe jigsaw nilai rata-rata 79,85 dengan kategori baik dan model kooperatif tipe two stay two stray nilai rata-rata 83,58 dengan kategori baik.
\end{abstract}

Kata kunci : jigsaw, two stay two stray, hasil belajar 


\section{Pendahuluan}

Pendidikan adalah usaha sadar yang dilakukan oleh keluarga, masyarakat dan pemerintah melalui kegiatan bimbingan, pengajaran atau latihan yang berlangsung di sekolah dan di luar sekolah sepanjang hayat, untuk mempersiapkan siswa agar dapat memainkan peranan dalam berbagai lingkungan hidup secara tepat di masa yang akan datang. Pendidikan dapat dimaknai sebagai proses mengubah tingkah laku anak didik agar menjadi manusia dewasa yang mampu hidup mandiri dan sebagai anggota masyarakat dalam lingkungan alam sekitar dimana individu itu berada.

Masalah yang dihadapi dalam dunia pendidikan salah satunya adalah seringnya siswa yang mendapatkan hasil belajar kurang dari standar Ketuntasan Belajar Minimal (KBM), akibatnya siswa tersebut akan mengikuti remedial untuk dapat mencapai standar KBM yang ditentukan. Hasil belajar dapat diartikan sebagai sebuah cerminan dari usaha belajar, semakin baik usaha belajar siswa idealnya semakin baik pula hasil belajar yang akan siswa raih. Hasil belajar sangat penting karena merupakan salah satu tujuan dalam dunia pendidikan.

Faktor yang mempengaruhi masalah pendidikan adalah model pembelajaran yang digunakan.Model pembelajaran yang tepat diharapkan dapat mengatasi permasalahan pendidikan yang ada. Model-model pembelajaran yang ada yaitu model pembelajaran project based,model pembelajaran inquiry, model pembelajaran discovery, model pembelajaran project based learningdan model pembelajaran cooperative.Berdasarkan penelitian yang dilakukan oleh Purwaningsih (2014) model pembelajaran kooperatif memiliki pengaruh yang signifikan dalam meningkatkan hasil belajar Fisika.Model pembelajaran kooperatif bermacammacam seperti Model pembelajaran kooperatif tipeNHT, jigsaw, Two Stay Two Stray (TSTS) dan lainnya. Model kooperatif Two Stay Two Stray (TSTS) merupakanmodel pembelajaranyang berkelompok dengan tujuan agar siswa dapat saling bekerja sama, bertanggung jawab, saling membantu dalam memecahkan masalah, dan saling mendorong untuk siswa satu sama lain untuk berprestasi. Metode ini juga melatih siswa untuk bersosialisasi dengan baik. Selain itu terdapat, Model pembelajaran jigsaw didesain untuk meningkatkan rasa tanggung jawab siswa terhadap pembelajarannya sendiri dan juga pembelajaran orang lain. Siswa tidak hanya mempelajari materi yang diberikan, tetapi juga harus siap memberikan dan mengajarkan materi tersebut kepada kelompoknya.jigsaw ini dapat meaktifkan siswa (student centered) sangat dibutuhkan, dengan dibentuknya kelompokkelompok kecil yang beranggotakan 3-5 orang yang terdiri dari kelompok asal dan kelompok ahli.

Model pembelajaran kooperatif tipe jigsaw dan tipe two stay two stray memiliki kesamaan yaitu siswa dapat bekerjasama dan saling membantu dalam memecahkan masalah dalam pembelajaran. Berdasarkan hasil dari beberapa penelitian sebelumnya menunjukkan bahwa model pembelajaran kooperatif tipe jigsaw dan tipe two stay two stray cukup memberikan hasil yang memuaskan terhadap hasil belajar.

Materi elastisitas bahan sangat cocok dengan model pembelajaran kooperatif tipe jigsaw dan tipe two stay two stray. Hal ini karena model kooperatif tipe jigsaw dan tipe two stay two stray memberikan kesempatan kepada siswa untuk saling berbagi informasi yang lebih dipahami kepada siswa yang lain.

Berdasarkan hasil wawancara dengan salah satu guru Fisika di MAN Model Palangka Raya, beliau mengatakan bahwa siswa sering remedial dalam mencapai KBM. Selain itu beliau juga belum pernah menggunakan model pembelajaran kooperatif tipe jigsaw dan tipe two stay two stray dalam pembelajaran, selain itu beliau menggunakan model pembelajaran langsung dalam pengajaran materi fisika Elastisitas bahan.

Berdasarkan uraian di atas, maka peneliti ingin mencoba mencari tahu peningkatan hasil belajar siswa dengan model kooperatif tipe jigsaw dan tipe two stay two stray. perbedaan hasil belajar siswa antara model kooperatif tipe jigsaw dan tipe two stay two stray serta aktivitas guru dan siswa menggunakan model kooperatif tipe jigsaw dan tipe two stay two stray.

\section{Metode Penelitian}

Penelitian ini menggunakan pendekatan kuantitatif dan jenis penelitian deskriptif dan komparatif. Desain penelitian ditunjukkan pada tabel 1. 
Tabel 1. Desain Penelitian

\begin{tabular}{llll}
\hline Kelompok & Pre-tes & Perlakuan & Post-tes \\
\hline Eksperimen 1 & $\mathrm{O}$ & $\mathrm{X}_{1}$ & $\mathrm{O}$ \\
Eksperimen 2 & $\mathrm{O}$ & $\mathrm{X}_{2}$ & $\mathrm{O}$ \\
\hline
\end{tabular}

(Sukmadinata (2011: 208))

Keterangan:

$\mathrm{O}$ :Pretes dan Posttes untuk kelompok eksperimen sebelum dan sesudah diberi perlakuan.

$\mathrm{X}_{1}$ : Perlakuan pada kelas eksperimen 1 dengan menggunakan model pembelajaran kooperatif tipe Jigsaw.

$\mathrm{X}_{2}$ : Perlakuan pada kelas eksperimen 2 dengan menggunakan model pembelajaran kooperatif tipe Two Stay Two Stray (TSTS).

Penelitian ini dilaksanakan di MAN Model Palangka Raya tahun ajaran 2017/2018 dan dilaksanakan mulai bulan Agustus sampai dengan bulan September 2017. Subjek penelitian dalam penelitian ini adalah kelas XI dengan sampel penelitian adalah kelas XI MIPA 5 diajar dengan model pembelajaran koopratif tipe jigsaw dan XI MIPA 6 diajar dengan model pembelajaran kooperatif tipe two stay two stray. Teknik pengambilan sampel pada penelitian ini menggunakan teknik judgment sampling.

Teknik pengumpulan data dengan melakukan wawancara, penyebaran angket, dan observasi. Instrumen yang digunakan pada penelitian ini adalah berupa test berupa soal uraian dan lembar pengamatan.

Teknik analisis yang dilakukan mencari nilai gaindan $n$-gain kedua kelas eksperimen. Langkah selanjutnya melakukan uji prasyarat analisis yaitu dengan melakukan uji normalitas untuk mengetahui normal atau tidaknya data yang diperoleh, uji homogenitas untuk mengetahui data yang diperoleh memiliki kesetaraan dan uji beda untuk mengetahui terdapat peningkatan dan perbedaan data yang diperoleh.

\section{Hasil Dan Pembahasan}

Nilai peningkatan hasil belajar kognitif siswa pada kedua kelas eksperimen terlihat pada tabel 2 berikut.
Tabel 2. Nilai rata-rata pretest, posttest, gain dan $n$-gain hasil belajar kognitif Kognitif

\begin{tabular}{lccccc}
\multirow{2}{*}{ Kelas } & \multirow{N}{*}{ N } & \multicolumn{5}{c}{ Rata-Rata } \\
& & Pretest & Posttestt & Gain & N-Gain \\
\hline Jigsaw & 33 & 20,27 & 67,68 & 47,41 & 0,59 \\
TSTS & 31 & 16,29 & 57,47 & 41,18 & 0,49 \\
\hline
\end{tabular}

Tabel 2 menunjukkan hasil belajar kognitif siswa dengan model pembelajaran kooperatif tipejigsaw dan tipe two stay two stray mengalami peningkatan, hal ini terlihat dari hasil gain yaitu 47,41 untuk kelas jigsaw dan 41,18 untuk kelas TSTS. Setelah dilakukan uji beda berpasangan dengan menggunakan uji Willcoxon diperoleh nilai sig $<0,05$ yaitu sebesar 0,000 pada kedua kelas eksperimen, maka terdapat perbedaan yang signifikan sehingga kedua kelas mengalami peningkatan yang signifikan untuk hasil belajar kognitif.

Hal ini dikarenakan dengan model pembelajaran kooperatif tipe jigsaw setiap siswa mendapatkan materi yang berbeda-beda untuk semua kelompok, siswa yang memiliki materi sama akan dikumpulkan menjadi suatu kelompok yang disebut kelompok ahli, siswa pada kelompok ahli akan saling berbagi informasi mengenai suatu materi tertentu kepada siswa yang lain, sehingga membuat siswa yang kurang memahami materi lebih memahami materi pelajaran, selain itu siswa juga lebih fokus karena hanya membahas suatu materi tertentu.

Hal ini juga yang membangun rasa tanggung jawab siswa terhadap tugas yang diberikan dan meningkatkan daya pikir sehingga siswa menjadi lebih aktif. Seperti yang dikemukakan bahwa salah satu cara yang dilakukan guru untuk meningkatkan hasil belajar siswa adalah dengan mengaktifkan siswa dalam proses pembelajaran.Pembelajaran kooperatif ini juga dapat meningkatkan prestasi (hasil) belajar siswa karena siswa diberikan kesempatan untuk saling belajar dengan sesamanya (Suhadi, 2010: 7).Keberhasilan tes hasil belajar kognitif dengan model pembelajaran Jigsaw telah dilakukan oleh Warnita (2014), dimana prestasi belajar mengalami peningkatan.

Peningkatan hasil belajar kognitif siswa dengan model TSTSdisebabkan karena dengan adanya kegiatan stay dan stray, siswa yang melakukan kegiatan stray akan bertanya mengenai materi yang belum dipahami kepada kelompok lain dan siswa yang melakukan kegiatan stay akan 
saling berbagi informasi yang diketahui sehingga siswa lebih memahami materi.

Menurut Hanafiah (2012) bahwa dengan model TSTS memberi kesempatan siswa untuk mengembangkan hasil informasi.Hal ini sejalan dengan penelitian yang dilakukan oleh Wahyuni (2012) dimana terdapat peningkatan yang signifikan hasil belajar siswa diajar dengan model TSTS. Yuhendrawati (2012) dalam penelitiannya menyebutkan bahwa salah satu kelebihan dari pembelajaran TSTS adalah membantu meningkatkan minat dan prestasi (hasil) belajar siswa. Hasil belajar afektif pada kedua kelas eksperimen dapat dilihat pada tabel 3 berikut.

Tabel 3. Nilai rata-rata pretest, posttest, gain dan n-gain hasil belajar Afektif Afektif

\begin{tabular}{lccccc}
\hline \multicolumn{6}{c}{ Afektif } \\
Kelas & \multirow{2}{*}{ N } & \multicolumn{4}{c}{ Rata-Rata } \\
& & Pretest & Posttestt & Gain & N-Gain \\
\hline Jigsaw & 33 & 54,54 & 88,89 & 34,34 & 0,75 \\
TSTS & 34 & 48,53 & 88,24 & 39,71 & 0,77 \\
\hline
\end{tabular}

Terlihat pada tabel 3 bahwa hasil belajar afektif siswa mengalami peningkatan yang signifikan yaitu pada nilai gainuntuk model pembelajaran kooperatif tipe jigsaw sebesar 34,34 dan model pembelajaran kooperatif tipe TSTS sebesar 39,71, hal ini dibuktikan dengan hasil uji Willcoxon diperoleh nilai sig $<0,05$ yaitu 0,000 maka terdapat perbedaan yang signifikan hasil belajar afektif siswa pada kedua kelas, sehingga hasil belajar afektif siswa pada kedua kelas mengalami peningkatan yang signifikan.

Hasil belajar afektif dengan model pembelajaran kooperatif tipe jigsaw mengalami peningkatan yang signifikan dikarenakan saat kegiatan berdiskusi berlangsung pada kelompok ahli, dimana siswa saling berbagi informasi mengenai apa yang diketahui dan saling memahami maksud dari materi yang didiskusikan. Model kooperatif jigsaw membuat siswa lebih fokus dalam memahami materi dan aktif mencari informasi karena siswa bertanggung jawab terhadap materi yang dimiliki, selain itu siswa akan dituntut untuk memahami materi serta mampu menjelaskan hasil diskusi bersama kelompok ahlinya terhadap kelompok asal.

Menurut Sugiyanto (2010: 46) keunggulan model jigsaw salah satunya adalah menumbuhkan rasa tanggung jawab siswa, serta akan merasa senang berdiskusi dalam kelompoknya. Hasil penelitian ini juga sesuai dengan penelitian Jati
(2016: 66) yaitu dengan model pembelajaran jigsaw dapat meningkatkan tanggung jawab siswa.

Hasil belajar afektif siswa yang diajar dengan model pembelajaran kooperatif tipe TSTS mengalami peningkatan yang signifikan.Peningkatan ini disebabkan oleh model pembelajaran kooperatif tipe TSTS yang digunakan, karena saat pembelajaran siswa dituntut untuk saling bersikap jujur dalam berbagi informasi saat melakukan kegiatan stay dan stray.Siswa dalam kegiatan pembeljaran cenderung menggunakan kemampuan berkomunikasi, hal itu terlihat saat kegiatan stay dan stray berlangsung dimana siswa saling berbagi dan menggali informasi antar kelompok.

Menurut Suprijono (2012: 93) bahwa model TSTS mendorong siswa memperoleh konsep secara mendalam melalui pemberian peran pada siswa.Hal ini sejalan dengan penelitian Astuti (2015) bahwa model TSTS mampu meningkatkan hasil belajar siswa. Hasil belajar psikomotorik pada kedua kelas eksperimen dapat dilihat pada tabel 4 berikut.

Tabel 4. Nilai rata-rata pretest, posttest, gain dan $n$-gain hasil belajar Psikomotorik

\begin{tabular}{lccccc}
\hline \multicolumn{5}{c}{ Psikomotorik } \\
Kelas & \multirow{N}{*}{ N } & \multicolumn{4}{c}{ Rata-Rata } \\
& & Pretest & Posttestt & Gain & N-Gain \\
\hline Jigsaw & 33 & 46,21 & 87,31 & 41,10 & 0,76 \\
TSTS & 34 & 59,56 & 88,4 & 28,85 & 0,71 \\
\hline
\end{tabular}

Tabel 4 menunjukkan hasil belajar psikomotorik siswa pada kedua kelas eksperimen. Hasil belajar psikomotorik mengalami peningkatan, pada nilai gain kedua kelas yaitu 41,10 untuk model pembelajaran kooperatif tipe jigsaw dan 28,85 untuk model pembelajaran kooperatif tipe two stay two stray.Hal ini dibuktikan dengan hasil uji coba menggunakan uji Willcoxon diperoleh nilai sig $<0,05$ yaitu 0,000 , maka terdapat perbedaan yang signifikan hasil belajar psikomotorik pada kedua kelas eksperimen, jadi terdapat peningkatan yang signifikan hasil belajar psikomotorik pada kedua kelas eksperimen.

Hasil belajar psikomotorik dengan model pembelajaran kooperatif tipe jigsawmengalami peningkatan yang signifikan terhadap dikarenakan siswa mampu bekerjasama dengan teman sekelompoknya saat melakukan kegiatan praktikum dan diskusi, karena siswa akan lebih 
fokus dengan percobaan pada materi yang sama sehingga dapat meningkatkan hasil belajar psikomotorik siswa. Siswa dengan materi yang sama akan saling membantu dalam kegiatan diskusi maupun eksperimen.

Menurut Sthal (Solihatin \&Raharjo, 2007: 5) bahwa model pembelajaran kooperatif menempatkan siswa sebagai bagian dari suatu sistem kerja sama dalam mencapai suatu hasil yang optimal dalam belajar. Menurut Rusman (2008: 203) Model pembelajaran jigsawmemberikan kesempatan kepada siswa untuk mengemukakan pendapat, mengelola informasi yang didapat, meningkatkan keterampilan berkomunikasi, bertanggung jawab terhadap keberhasilan kelompok dan ketuntasan bagian materi yang dipelajari.

Hasil belajar psikomotorik siswa yang diajar dengan model pembelajaran kooperatif tipe TSTS mengalami peningkatan yang signifikan, Keberhasilan model pembelajran TSTS terhadap hasil belajar psikomotorik siswa dikarenakan siswa dalam melakukan percobaan saling bekerja sama dengan kelompoknya selain itu saat siswa melakukan kegiatan stay dan stray siswa bertanya kepada kelompok lain untukmemperdalam cara menggunakan alat dalam melakukan percobaan. Hal ini sejalan dengan penelitian Eni (2009) bahwa model pembelajaran kooperatif tipe TSTS berpengaruh terhadap hasil belajar siswa. Hasil uji beda untuk perbedaan hasil belajar kognitif siswa dapat dilihat pada tabel 5 berikut.

\section{Tabel 5.Hasil Uji Beda Berpasangan hasil belajar kognitif siswa}

\begin{tabular}{|c|c|c|}
\hline Variabel & Uji beda & Sig* \\
\hline Pretest & Independent Sampel T-Tes & 0,717 \\
\hline Posttestt & Mann-Whitney U & 0,343 \\
\hline Gain & Mann-Whitney U & 0,856 \\
\hline N-Gain & Mann-Whitney U & 0,687 \\
\hline
\end{tabular}

Pada tabel 5 terihat nilai posttest hasil belajar kognitif siswa dengan uji beda menggunakan rumus Mann-Whitney $U$ diperoleh nilai sig > 0,05 yaitu 0,343 , maka tidak terdapat perbedaan yang signifikan hasil belajar kognitif siswa yang diajar dengan model kooperatif tipe jigsaw dan tipe TSTS.Model jigsaw dan TSTS ini menjadikan siswa lebih aktif dalam berkomunikasi, lebih mudah memahami materi, meningkatkan kerjasama dan kepercayaan antar siswa. Siswa akan saling berbagi informasi mengenai materi yang lebih dipahami ke siswa yang kurang memahami.

Walaupun keduanya tidak memiliki perbedaan yang signifikan namun model pembelajaran kooperatif tipe jigsaw secara persentase lebih unggul dari pembelajaran kooperatif tipe TSTS. Hal ini dikarenakan tingkat kefokusan siswa dalam memahami materi pada model jigsaw lebih baik daripada model TSTS. Keunggulan model jigsaw ini diakibatkan dengan adanya kelompok ahli.Kelompok ahli membuat siswa akan mendiskusikan materi yang sama, sehingga siswa lebih mampu fokus ketimbang dengan menggunakan model TSTS dalam berdiskusi dan lebih memahami materi yang didiskusikan.

Hal ini dibuktikan berdasarkan pendapat Arends (2001: 23) bahwa keunggulan model jigsaw yaitu pemahaman siswa pada sebuah materi akan lebih mendalam. Selain itu, terlihat dari kelebihan model jigsaw menurut Ibrahim (2000)yaitu siswa akan lebih menguasai dan memahami materi karena mampu mengajarkan materi tersebut kepada teman kelompoknya. Hal ini sejalan dengan penelitian Soleha (2015) yang mengatakan bahwa model kooperatif tipe jigsaw lebih unggul dibandingkan model kooperatif tipe two stay two stray. Hasil uji beda untuk perbedaan hasil belajar afektif siswa dapat dilihat pada tabel 6 berikut.

\section{Tabel 6.Hasil Uji Beda Berpasangan hasil belajar afektif siswa}

\begin{tabular}{ccc}
\hline Variabel & Keputusan & Sig* \\
\hline Pretest & Mann-Whitney $U$ & 0,012 \\
Posttestt & Mann-Whitney $U$ & 0,795 \\
Gain & Mann-Whitney $U$ & 0,137 \\
N-Gain & Mann-Whitney $U$ & 0,769 \\
\hline
\end{tabular}

Tabel 6 menunjukkan hasil uji beda hasil belajar afektif siswa dengan hasil uji beda menggunakan rumus uji Mann-Whitney $U$ diperoleh nilai sig $>0,05$ yaitu 0,769 , maka tidak terdapat perbedaan yang signifikan hasil belajar afektif siswa antara kedua kelas eksperimen. Berdasarkan fakta dilapangan menunjukkan bahwa model jigsaw sama halnya dengan model two stay two stray membuat siswa aktif dalam kegiatan berdiskusi, pada saat pembelajaran berlangsung dengan model jigsaw siswa akan lebih aktif berdiskusi ketimbang model TSTS, hal ini dikarenakan siswa pada model jigsaw 
mempunyai tanggung jawab untuk memahami materi yang telah ditentukan kepada siswa sehingga mampu menumbuhkan rasa tanggung jawab siswa lebih besar ketimbang model TSTS.

Model kooperatif tipe TSTS lebih unggul dalam meningkatkan sikap jujur siswa, hal ini terlihat pada saat siswa melakukan kegiatan stay dan stray siswa akan menunjukkan sikap jujur karena informasi yang dibagikan sangat penting untuk pemahaman kelompom lain. Dengan sesama keunggulan pada masing-masing bidang inilah yang mengakibatkan kedua model ini tidak memiliki perbedaan yang signifikan dalam keseluruhan perningkatan hasil belajar afektif siswa jika dilihat dari keseluruhan indikator.Hal ini sejalan dengan penelitian yang dilakukan oleh Raras (2015) bahwa tidak terdapat perbedaan yang signifikan hasil belajar siswa dengan model jigsaw dan model two stay two stray. Hasil uji beda untuk perbedaan hasil belajar psikomotorik siswa dapat dilihat pada tabel 7 berikut.

Tabel 7.Hasil Uji Beda Berpasangan hasil belajar psikomotorik siswa

\begin{tabular}{ccc}
\hline Variabel & Keputusan & Sig* \\
\hline Pretest & Mann-Whitney $U$ & 0,000 \\
Posttestt & Mann-Whitney $U$ & 0,768 \\
Gain & Mann-Whitney $U$ & 0,001 \\
N-Gain & Mann-Whitney $U$ & 0,387 \\
\hline
\end{tabular}

Tabel 7 menunjukkan hasil uji beda tes hasil belajar psikomotorik siswa diperoleh nilai sig > 0,05 yaitu sebesar 0,387 maka tidak terdapat perbedaan yang signifikan hasil belajar psikomotorik siswa yang diajar menggunakan model pembelajaran tipe jigsaw dan tipe TSTS.Fakta dilapangan menunjukkan bahwa pada model kooperatif tipe jigsaw siswa akan saling membantu dalam melakukan percobaan, hal ini karena siswa dengan materi yang sama maka tujuan yang dicapaipun sama sehingga keterampilan siswa dalam menggunakan, merancang, mengukur dan menghitung akan meningkat secara bersama-sama.

Model kooperatif tipe TSTS bahwa siswa akan aktif dalam memahami materi dan saling bekerja sama dalam melakukan percobaan sehingga meningkatkan kemampuan keterampilan siswa baik itu menggunakan, merancang, mengukur maupun menghitung, selain itu pada kegiatan stay dan stray membuat siswa lebih meningkatkan pemahaman materi yang belum dipahami, siswa dapat menanyakan cara menggunakan, merancang, mengukur ataupun menghitung konstanta pegas kepada kelompok lain. Siswa yang kena bagian stray harus mampu memahami penjelasan yang diberikan oleh siswa kelompok lain yang kena bagian menjadi stray. Hal ini sejalan dengan penelitian Soleha (2015) yang mengatakan bahwa model kooperatif tipe jigsaw dan tipe TSTS tidak terdapat perbedaan yang signifikan pada hasil belajar siswa. Aktivitas guru menggunakan model pembelajaran kooperatif tipe jigsaw dapat dilihat pada diagram berikut.

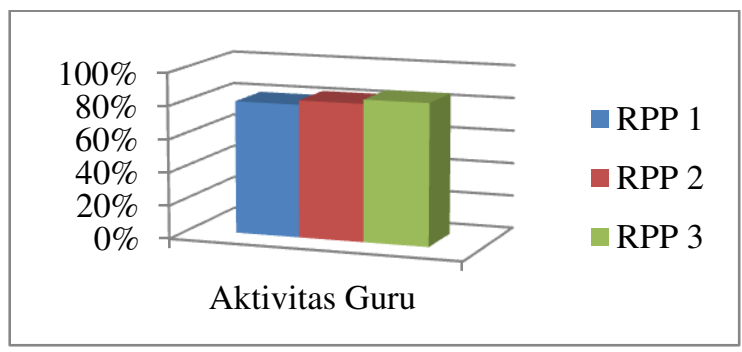

Gambar 1. Aktivitas guru kelas jigsaw

Gambar 1 menujukkan aktivitas guru untuk tiap-tiap RPP, terlihat bahwa guru telah melakukan kegiatan pembelajaran kooperatif tipejigsaw sesuai dengan syntax model jigsaw. Hal ini terlihat bahwa persentase aktivitas guru mengalami peningkatan pada RPP 1 sebesar $80 \%$, pada RPP 2 sebesar $83 \%$ dan pada RPP 3 sebesar $86 \%$ dengan kategori baik. Pada setiap RPP yang tak pernah dilewati oleh peneliti adalah pada langkah 7 yaitu dimana peneliti atau guru membagikan materi untuk tiap-tiap siswa pada semua kelompok, langkah 8 yaitu dimana guru mempersilahkan siswa yang mendapatkan materi yang sama untuk berkumpul membentuk kelompok ahli, dan langkah 14 yaitu dimana guru memberikan penguatan materi kepada siswa mengenai materi yang belum dipahami, peneliti menambahkan materi yang belum dipahami dan diketahui oleh siswa.

Proses pembelajaran tidak mungkin terjadi pada siswa apabila guru tidak memberikan perlakuan (Sanjaya, 2006: 104). Perlakuan yang dimaksud adalah pemberian materi pembelajaran. Aktivitas guru menggunakan model pembelajaran kooperatif tipe two stay two stray dapat dilihat pada diagram berikut. 


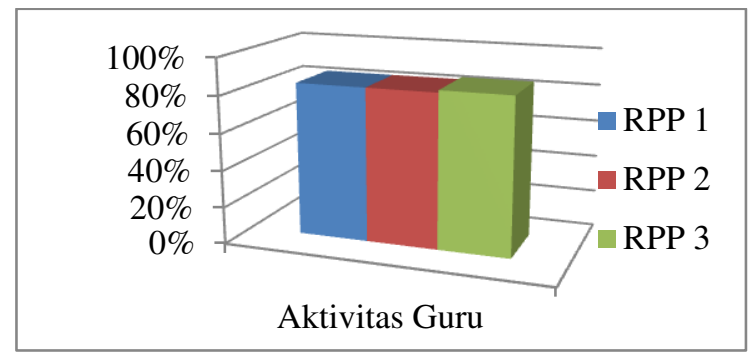

Gambar 2 aktivitas guru model TSTS

Gambar 2 menunjukkan diagram aktivitas guru pada model TSTS dari RPP pertama hingga RPP terakhir. Aktivitas yang dilakukan oleh peneliti sebagai guru telah sesuai dengan syntax model pembelajaran yang digunakan hal ini dibuktikan dengan persentase yaitu pada RPP 1 sebesar 84\%, RPP 2 sebesar $84 \%$ dan pada RPP 3 sebesar $85 \%$ dengan kategori baik. Beberapa langkah pembelajaran yang selalu dilakukan oleh peneliti adalah Pada kegiatan langkah 5 guru menjelaskan materi secara umum, guru menjelaskan materi hanya berupa hal-hal yang akan memancing siswa untuk tertarik memahami materi yang akan dipelajari.

Proses pembelajaran tidak mungkin terjadi pada siswa apabila guru tidak memberikan perlakuan (Sanjaya, 2006: 104). Perlakuan yang dimaksud adalah pemberian materi pembelajaran. Langkah 15 yaitu guru melakukan evaluasi terhadap kinerja kelompok, peneliti melakukan evaluasi dengan cara melihat hasil presentasi siswa dan hasil dari quis yang telah dijawab oleh siswa. Evaluasi adalah proses untuk memperoleh informasi yang berguna untuk mempertimbangkan suatu keputusan (Gibson, 1981: 374). Aktivitas siswa menggunakan model pembelajaran kooperatif tipe jigsaw dapat dilihat pada diagram berikut

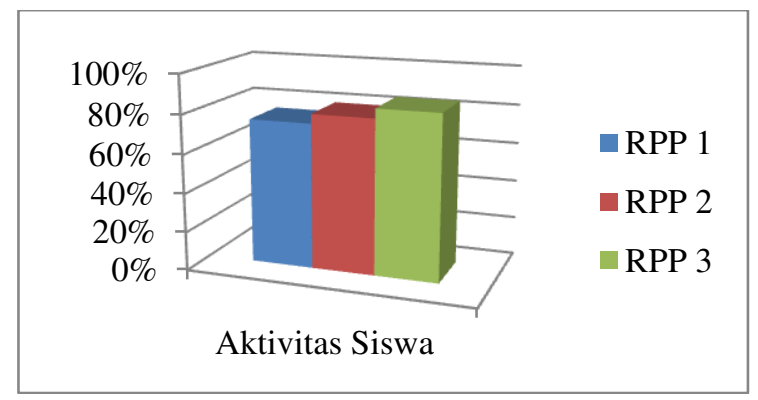

Gambar 3 aktivitas siswa model jigsaw

Gambar 3 menunjukkan diagram aktivitas siswa menggunakan model pembelajaran kooperatif tipe jigsaw, terlihat bahwa pada setiap
RPP terjadi kenaikan aktivitas siswa. Pada RPP 1 yaitu sebesar 75\%, RPP 2 sebesar 80\% dan RPP 3 sebesar $85 \%$ dengan kategori baik, Aspek yang mengalami peningkatan paling tinggi adalah pada langkah ke 7 yaitu siswa menerima materi yang telah ditentukan oleh guru, pada saat kegiatan siswa menerima materi yang telah ditentukan oleh guru kemudian saling berbagi materi yang ingin dipelajari.

Bahan pelajaran (materi) merupakan seperangkat materi pelajaran yang tersusun secara runtut dan sistematik serta menampilkan sosok utuh dari kompetensi yang akan dikuasai siswa dalam kegiatan pembelajaran (Aksan, 2014: 4). Kegiatan pembelajaran siswa harus berbuat aktif yaitu diperlukannya sebuah aktivitas, tanpa aktivitas proses pembelajaran tidak akan terlaksana dengan baik (Sardiman, 2011: 97). Aktivitas siswa menggunakan model pembelajaran kooperatif tipe two stay two stray dapat dilihat pada diagram berikut

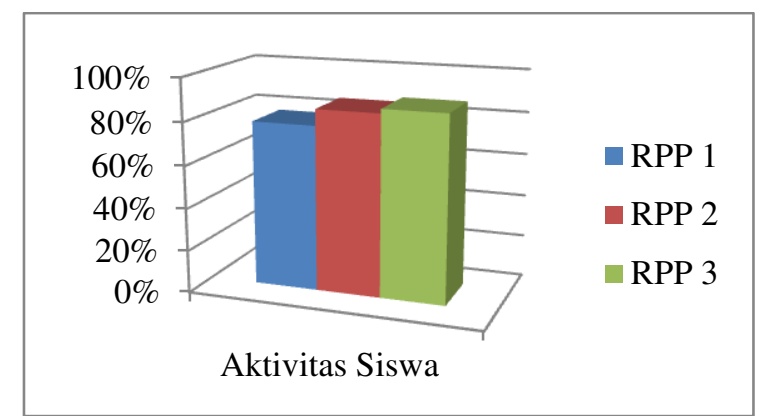

Gambar 4 aktivitas siswa model TSTS

Gambar 4 menunjukkan aktivitas siswa menggunakan model pembelajaran kooperatif tipe two stay two stray. terlihat bahwa terjadi peningkatan aktivitas siswa dari RPP 1 hingga RPP 3, pada RPP 1 sebesar 78\%, RPP 2 sebesar $85 \%$ dan RPP 3 sebesar $88 \%$. aspek yang mengalami peningkatan paling tinggi terjadi pada ranah ke 10 yaitu siswa selesai melakukan berdiskusi, hal ini dibuktikan dengan fakta dilapangan bahwa siswa selalu tepat waktu dalam menggunakan waktu yang telah diberikan untuk melakukan kegiatan berdiskusi, apabila peneliti mengumumkan waktu untuk berdiskusi telah selesai maka siswa akan langsung berhenti untuk melakukan diskusi.

Disiplin ialah suatu sikap menghormati dan menghargai suatu peraturan yang berlaku, baik secara tertulis maupun tidak tertulis serta sanggup menjalankannya dan tidak menolak untuk menerima sanksi-sanksi apabila dia melanggar 
tugas dan wewenang yang diberikan kepadanya (Hasibuan, 2002).Hal ini sejalan dengan penelitian yang dilakukan oleh Dewi (2013) bahwa semakin tinggi keakuratan tepat waktu yang dilakukan oleh seseorang (siswa) maka semakin besar kualitas dari informasi yang diperoleh.

\section{Simpulan Dan Saran}

\section{Simpulan}

Hasil penelitian ini dapat disimpulkan (1) terdapat peningkatan yang signifikan hasil belajar siswa. Hal itu terlihat dari nilai sig $<0,05$, (2) Tidak terdapat perbedaan yang signifikan hasil belajar siswa antara model pembelajaran kooperatif tipe jigsaw dan tipe two stay two stray. hal itu terlihat dari nilai sig > 0,05, (3) Penilaian aktivitas guru menggunakan model pembelajaran kooperatif tipe jigsaw secara keseluruhan didapatkan rata-rata penilaian sebesar 82,89 dengan kategori baik, sedangkan penilaian aktivitas guru menggunakan model pembelajaran kooperatif tipe two stay two stray secara keseluruhan didapatkan rata-rata penilaian sebesar 84,17 dengan kategori baik. Penilaian aktivitas siswa menggunakan model pembelajaran kooperatif tipe jigsaw secara keseluruhan didapatkan rata-rata penilaian sebesar 79,85 dengan kategori baik, sedangkan penilaian aktivitas siswa menggunakan model pembelajaran kooperatif tipe two stay two stray secara keseluruhan didapatkan rata-rata penilaian sebesar 83,58 dengan kategori cukup baik.

\section{Saran}

Untuk penelitian selanjutnya diharapkan peneliti terlebih dahulu melakukan observasi awal terhadap waktu atau jadwal belajar siswa dan kegiatan-kegiatan yang mungkin dapat mengganggu jadwal penelitian.

\section{Daftar Pustaka}

Aksan, Hernawan. 2014. Seri Pendidikan Budaya dan Karakter Bangsa. Bandung: Nuansa Cendekia.

A.M, Sardiman. 2011. Interaksi dan Motivasi Belajar-Mengajar. Jakarta: Rajawali Pers.

Arends, R.I. 2001. Exploring Teaching: An Introduction to Education.New York: Mc Graw-Hill Companies.
Astuti, Sri. 2015. Penerapan Model Kooperatif Tipe Two Stay Two Stray Pada Pembelajaran Fisika Siswa Kelas XI SMA Negeri Jayaloka tahun Pelajaran 2014/2015. STKIP-PGRI Lubuk Linggau.

Dewi, Resita Pristiana. 2013. Pengaruh Keakuratan, Tepat Waktu, Keandalan Dan Relevansi Terhadap Kepuasan Pengguna Sistem Informasi Akuntansi Pada PT Garam (PERSERO) Surabaya.Skripsi.STIESIA Surabaya.

Hanafiah, dkk. 2009. Konsep Strategi Pembelajaran. Bandung: Aditama.

Hasibuan, Malayu S.P. 2002. Manajemen Sumber Daya Manusia. Jakarta: Bumi Aksara.

Ibahim, dkk. 2000. Pembelajaran Kooperatif. Jakarta: UNESA-University Press.

Jati, Niko Kumala. 2016. Meningkatkan Tanggung Jawab Siswa Menggunakan Model Pembelajaran Kooperatif Tipe Jigsaw II Pada Mata Pelajaran Matematika Kelas IV SDN Sapen Manis Renggo Klaten Tahun Ajaran 2015/2016.Skripsi.Universitas Negeri Yogyakarta.

Purwaningsih, Ariyati \& Panjaitan. 2014. Penerapan Model Pembelajaran Kooperatif Tipe Two Stay Two Stray Terhadap Hasil Belajar Dan Sikap Ilmiah Siswa Pada Materi Keanekaragaman Hayati Di Kelas X MAN 1 Pontianak. Jurnal Pendidikan Matematika dan IPA.Pontianak : FKIP Universitas Tanjungpura.

Raras, Aristin, dkk. Perbandingan Hasil Belajar Fisika Siswa Yang Menggunakan model Pembelajaran Kooperatif Tipe Jigsaw Dengan Discovery-Inquiry Di SMA.Seminar nasional Fisika Volume IV.

Rusman.2008. Pembelajaran Kooperatif Tipe Jigsaw.http://style-

lecture.blogspot.com/2012/09/pembelajar an-kooperatif-model-jigsaw.html.

Sanjaya, Wina. 2006. Strategi Pembelajaran. Jakarta: Kencana Prenada Media Group.

Soleha, lutfi Awaliyah. 2015. Perbedaan Hasil Belajar Antara Siswa Yang Menggunakan Metode Pembelajaran Two Stay Two Stray Dan Jigsaw Pada Konsep Sistem 
Pencernaan. Skripsi.UIN Syarif Hidayatullah.

Solihatin \& Raharjo. 2007. Cooperative Learning (Analisis Pembelajaran IPS). Jakarta: Bumi Aksara.

Sugiyanto. 2010. Model-Model Pembelajaran Inovatif. Surakarta: Yuma Pustaka.

Suhadi.2010. Karakteristik Dan Tujuan Model Pembelajaran Kooperatif. Ebook: Alifa Alternative Media. Diunduh dari http://suhadinet.wordpress.com.pada tanggal 20 Oktober 2017.

Sukmadinata, Nana syaodih. 2013. Metode Penelitian Pendidikan. Bandung: PT Remaja Rosdakarya.

Suprijono, Agus. 2009. Cooperative Learning (Teori Dan Aplikasi Paikem). Yogyakarta: Pustaka Pelajar.

Wahyuni \& Munthe. 2014. Pengaruh Model Pembelajaran Kooperatif Tipe Two Stay Two Stray (TSTS) Terhadap Hasil Belajar Siswa Pada Materi Listrik Dinamis Pada Siswa SMA. Jurnal Pendidikan Fisika : FMIPA Unimed.

Warnita, I Dewa Made. 2015. Penerapan Model Pembelajaran Kooperatif Tipe Jigsaw Untuk Meningkatkan Prestasi Belajar Fisika Siswa Kelas XI IPA 4 SMA Negeri 1 Selemedag Tahun Pelajaran 2014/2015.JPTK.UNDIKSHA.

Yuhendrawati. 2012. Penerapan Model Pembelajaran Kooperatif Tipe Two Stay Two Stray Untuk Meningkatkan Hasil Belajar IPS Siswa Kelas IV.A Sekolah Dasar Negeri 164 Pekanbaru.Program Studi Pendidikan Guru Sekolah Dasar Jurusan Ilmu Pendidikan FKIP Universitas Riau. 